\title{
Genetic Diversity in Future Important under Utilized Crop Grain Amaranth (Amaranthus hypochondriacus L.) Genotypes based on Cluster
}

\author{
V.A. Raut, S.S. Dodake and N.M. Magar* \\ Department of Agriculture Botany, PGI, MPKV, Rahuri, India \\ *Corresponding author
}

\begin{abstract}
A B S T R A C T
In the present investigation, twenty eight genotypes of grain amaranth (Amaranthus hypochondriacus L.) were evaluated for their genetic divergence at field level using a randomized block design. The analysis of morphological variance exhibited significant differences among the genotypes for all the nine characters indicating the presence of substantial degree of variability. It was observed that the estimates for genotypic coefficients of variation (GCV) were equal to or lowest than the phenotypic coefficient of variation for all the characters. Grain weight $(\mathrm{g} / 10 \mathrm{ml})$ exhibited the lowest GCV (3.75) while grain yield per plant (g) and grain yield per plot had the highest GCV (29.31) as well as PCV (31.90). The lowest heritability (b.s) was observed for width of inflorescence (53\%). The highest heritability (b.s) was exhibited by days to $50 \%$ flowering (100\%), days to maturity $(100 \%)$ and grain weight $(100 \%)$. The characters plant height at maturity (30.82) showed higher genetic advance followed by days to maturity (12.34). Mahalanobis $\mathrm{D}^{2}$ analysis revealed the presence of high amount of genetic diversity among 28 genotypes, which formed five clusters. The cluster I contained maximum i.e. 12 genotypes while in cluster II, there were 8 genotypes. Cluster III having 5 genotypes, Cluster V having 2 genotypes and Cluster IV was monogenotypic.
\end{abstract}

\section{Keywords}

Genetic Diversity

Amaranth,

Amaranthus

hypochondriacus

\section{Article Info}

Accepted:

14 November 2020

Available Online:

10 December 2020

\section{Introduction}

Grain amaranth

(Amaranthus

hypochondriacus L.) is important pseudocereals that are widely cultivated in India, in the sub-Himalayan ranges and in the Nilgiri Hills of South India under the common name of Ramdanaa or Rajgira. It is an ancient food crop reported to have been cultivated in Mexico. Amongst the three pseudo-cereals (chenopods - Chenopodium spp., buckwheatFagopyrum spp. and amaranth - Amaranth spp.) grain amaranth are the most important underutilized crop having potential. The genus Amaranth is one of the annual coarse herbs distributed in temperate and tropical regions of the world (Sauer, 1967). De Candolle (1883) and Vavilov (1951) considered Indo-Burma region to be its centre of origin, like Amaranth cruentus (L.). The genus is dibasic with $\mathrm{X}=16$ chromosomes, almost equally distributed in section amaranth.

In North Indian hills, the grain crop is planted at the break of Monsoon and in South Indian 
hills; it is grown throughout the year. In India, amaranth assumes special significance as they are consumed during the religious days of fast. The seeds of Amaranth are popped to be used in the preparation of Laddoos. It is also added to a mixture of flour to make pastries of pancakes, while the young leaves are used in soups. The leaves of amaranth are eaten in soups, broths and as a vegetable and are used in protein extracts, colouring and laxatives. The inflorescences are used for decoration and the stems as animal feed and fuel (Ravindra et al., 1996). An interesting application of amaranth is to use it as a food for people with allergies to other grains. It is unrelated to any other food crops that are commonly consumed, which makes it less likely to cause problems to people who have build up allergies.

Although grain amaranth is an ancient food crop of the old and new worlds, surprisingly very less breeding work has been done in any country to produce improved varieties of this protein rich grain. Thus analysis of genetic relationship in crop species is important component of crop improvement programme as it seems to provide information about genetic diversity. The Mahalanobis $\mathrm{D}^{2}$ statistcs is a powerful tool in quantifying the degree of divergence among genotypes. The distance between two clusters is the measure of the degree of divergence. Genotypes can grouped into different clusters by following Tochers method (Rao, 1952). The wide range of genetic diversity in grain amaranth indicates the possibility of improving its productivity.

\section{Materials and Methods}

The present investigation "Genetic diversity of future important underutilized crop grain amaranth (Amaranthus hypochondriacus L.) genotypes based on cluster" was carried out at All India Coordinated Research Network on
Underutilized Crops, Mahatma Phule Krishi Vidyapeeth, Rahuri. The twenty eight genotypes of Amaranthus hypochondriacus L. for the present investigation were obtained from the Plant Breeder, AICRP on Underutilized Crops, Mahatma Phule Krishi Vidyapeeth, Rahuri. The experiment was conducted during 2011-12 in Randomised Block Design with three replications with spacing of $45 \times 15 \mathrm{~cm}$. All the standard cultural practices such as fertilizer application, interculturing, weeding etc., were followed to raise good crop. Days to 50 per cent flowering (No.), days to maturity (Nos.), plant height at maturity $(\mathrm{cm})$, length of inflorescence $(\mathrm{cm})$, width of inflorescence $(\mathrm{cm})$, stem girth $(\mathrm{cm})$, grain yield per plot $(\mathrm{g})$, grain yield per plant (g) and grain Weight $(\mathrm{g} / 10 \mathrm{ml})$ and were recorded on ten randomly selected plants from each genotypes in each replication and averages were worked out.

\section{Statistical analysis}

The analysis of variance was done according to Panse and Sukhatme (1985), the genotypic and phenotypic coefficient of variation were calculated by formula suggested by Burton (1952), heritability percentage in broad sense was calculated as per the formula given by Burton (1952) and genetic advance was calculated by the formula suggested by Johnson et al., (1955).

\section{Mahalanobis generalized distance $\left(\mathrm{D}^{2}\right)$}

The generalized distance between two populations is defined by Mahalanobis (1936) as:

$$
D^{2}=\sum \lambda \text { i.j.. di. dj. }
$$

Where,

$\lambda$ i.j. $=$ Reciprocal matrix to the common dispersion matrix. 
di $=$ Difference between the mean values of two population for $\mathrm{i}^{\text {th }}$ character.

$\mathrm{dj}=$ difference between the mean values of two population for $\mathrm{j}^{\text {th }}$ character.

Estimation of $\mathrm{D}^{2}$ values from the above formula is very complicated in the present study. Since, it requires the inversion of a thirteenth order determinant and then the evaluation of $\mathrm{B}(\mathrm{BH}) / 2$ terms whose sum is $\mathrm{D}^{2}$. It was found convenient to work with a set of uncorrelated characters constructed from the original measurements. $\mathrm{D}^{2}$ with such transformed variables reduces to the evaluation of a simple sum of squares. Transformation was done by using pivotal condensation method (Singh and Chaudhary, 1977). The coefficients for the transformation were obtained by dividing the first row of the reduced matrix by the square root of the corresponding pivotal condensation elements. Tocher's method as described by Rao (1952) was followed for cluster formation.

\section{Results and Discussion}

The mean performance of nine characters in twenty eight genotypes of grain amaranth is presented in Table 1. The genotype SKGPA27 flowered in 81.00 days and was the earliest among all genotypes. Maximum days for 50\% flowering recorded by genotypes by SKGPA20 (97.00 days) and SKGPA-21 (97.00 days). Days required for maturity ranged between 120.00 (BGA-29) to 141.00 days (SKGPA-1). The general mean for this character was 133.14 days. SKGPA-41 $(148.77 \mathrm{~cm})$ was the tallest among all genotypes followed by SKGPA-1 $(146.77 \mathrm{~cm})$. The dwarf genotype was SKGPA-52 $(83.70 \mathrm{~cm})$. The mean for inflorescence length was $41.84 \mathrm{~cm}$ having the range of 34.27 to $52.20 \mathrm{~cm}$. The minimum inflorescence length was observed for SKGPA-20 $(34.27 \mathrm{~cm})$ followed by BGA-42 $(34.67 \mathrm{~cm})$ and the maximum inflorescence length was of genotypes RGAS-92-10-1 $(52.20 \mathrm{~cm})$. The mean for width of inflorescence was $10.49 \mathrm{~cm}$ having the range of 8.67 (SKGPA-20) to $13.30 \mathrm{~cm}$ (RGAS-9210-1). The mean for stem girth was $1.73 \mathrm{~cm}$ having the range of 0.96 to $2.67 \mathrm{~cm}$. The minimum stem girth was observed in SKGPA-52 $(0.96 \mathrm{~cm})$ followed by SKGPA$10(0.97 \mathrm{~cm})$ and the maximum stem girth was of genotypes SKGPA-41 $(2.67 \mathrm{~cm})$. The mean for grain weight was $8.57 \mathrm{~g} / 10 \mathrm{ml}$ having the range of 7.75 to $9.17 \mathrm{~g} / 10 \mathrm{ml}$. The genotype with minimum grain weight was SKGPA-1 followed by Suvarna (7.87 g/10 $\mathrm{ml}$ ) and the genotype having maximum grain weight was SKGPA-23. The mean for grain yield per plant was $15.25 \mathrm{~g}$ having the range of 7.90 (BGA-49) to $24.33 \mathrm{~g}$ (SKGPA-18). The mean for grain yield per plot was 594.15 $\mathrm{g}$ having the range of 284.33 (BGA-49) to $876.33 \mathrm{~g}$ (KGPA-18).

The analysis of variance for nine characters is presented in Table 2. It revealed that there were highly significant differences among the genotypes for all the characters under study. It indicated the presence of appreciable amount of diversity among genotypes.

The range of variability estimates of genotypic and phenotypic coefficient of variation, heritability percentage in broad sense, genetic advance and genetic advance at percentage mean is presented in Table 3. It was observed that the estimates for genotypic coefficients of variation (GCV) were equal to or lowest than the phenotypic coefficient of variation for all the characters. Grain weight $(\mathrm{g} / 10 \mathrm{ml})$ exhibited the lowest GCV (3.75) while grain yield per plant $(\mathrm{g})$ and grain yield per plot had the highest GCV (29.31) as well as PCV (31.90). It was followed by stem girth (27.98),plant height, length of inflorescence and width of inflorescence. The highest difference in GCV and PCV was observed in width of inflorescence (3.82) followed by 
length of inflorescence (3.59). High estimates of variability (b.s.) were observed for all the character studied. The lowest heritability (b.s) was observed for width of inflorescence (53\%). The highest heritability (b.s) was exhibited by days to $50 \%$ flowering (100\%), days to maturity (100\%), grain weight (100\%). The characters plant height at maturity (30.82) showed highest genetic advance, followed by days to maturity (12.34). The lowest genetic advance (0.66) was observed for grain weight.

These 28 genotypes were grouped in 5 clusters following Tochers method as described by Rao (1952). These clusters along with genotypes included under them are presented in Table 4. The cluster I contained maximum i.e. 12 genotypes while in cluster II, there were 8 genotypes. Cluster III having 5 genotypes, Cluster $\mathrm{V}$ having 2 genotypes, Cluster IV was monogenotypic.

Intra and inter cluster $\mathrm{D}^{2}$ values were worked out using $\mathrm{D}^{2}$ values from divergence analysis (Table 5). The minimum intra cluster distance $\left(D^{2}\right)$ was found in cluster IV being monogenotypic equal to 0.00 . The minimum inter cluster Distance $\left(\mathrm{D}^{2}\right)$ was observed between cluster I and IV (1416.77) followed by cluster I and cluster II (2791.01) and Cluster II and Cluster III (3216.02). Cluster means for nine characters (Table 6) revealed wide range of variability among 28 genotypes studied.

Cluster means for days to $50 \%$ flowering ranged from 88.25 in cluster II to 94 in Cluster IV. Cluster mean for days to maturity ranged from 132.38 in cluster II to 140.00 in cluster IV. Cluster means for plant height at maturity ranged from 97.69 to 137.12 . Cluster mean performance for length of inflorescence ranged from 37.20 in cluster $\mathrm{V}$ to 43.68 in Cluster I. Cluster mean for width of inflorescence ranged from 9.40 in cluster $\mathrm{V}$ to
10.94 in cluster I. Cluster mean for stem girth ranged from 1.56 in cluster I to 2.02 in cluster II. Cluster mean for grain yield per plant is ranged from 14.93 of Cluster I to 19.86 of cluster IV. Cluster mean for grain yield per plot is ranged from 537.47 in Cluster I to 715.00 in cluster IV.

The per cent contribution of 9 characters studied (Table 7), it was observed that grain weight contributed highest $(87.83 \%)$ for divergence and it was followed by stem girth $(8.20 \%)$, days to maturity $(2.65 \%)$, days to $50 \%$ flowering $(1.32 \%)$.

The genetic diversity present in any crop plays an important role in the improvement of that crop through plant breeding programme. Hence the assessment of genetic diversity in the available germplasm is of immense value to design a suitable selection procedure and its exploration of genetic upgradation of biological population.

Based on the analysis of variance for various characters the sum of squares due to treatment was significant for all characters. The wide range of variations among the genotypes paves the way to bring a desirable improvement in grain amaranth crops. A wide range of variability was observed in respect of days to $50 \%$ flowering (81 to 97 days), days to maturity (120 to 141 days), plant height at maturity $(83.07$ to $148.77 \mathrm{~cm})$, length of inflorescence $(34.67$ to $52.20 \mathrm{~cm})$, width of inflorescence $(8.67-13.03 \mathrm{~cm})$ stem girth $(0.97-2.67 \mathrm{~cm})$, grain yield per plant $(7.90$ to $24.83 \mathrm{~g}$ ), grain yield per plot (284.33 to $864.33 \mathrm{~g}$ ), grain weight (7.74 to $9.10 \mathrm{~g} / 10$ $\mathrm{ml}$ ). This indicated an ample scope for exploration of above traits as high amount of variation was observed. Kamble (2000) also reported wide range of variability in respect of days to maturity, plant height, inflorescence length, inflorescence width and grain yield per plant in grain amaranth. 
Table.1 Mean performance of twenty eight genotypes of Grain amaranth for various quantitative characters

\begin{tabular}{|c|c|c|c|c|c|c|c|c|c|c|}
\hline $\begin{array}{l}\text { Sr. } \\
\text { No. }\end{array}$ & Chariety & $\begin{array}{c}\text { Days to } \\
50 \% \\
\text { flowering }\end{array}$ & $\begin{array}{c}\text { Days to } \\
\text { Maturity }\end{array}$ & $\begin{array}{c}\text { Plant } \\
\text { height at } \\
\text { Maturity } \\
\text { (cm) }\end{array}$ & $\begin{array}{l}\text { Length of } \\
\text { inflorescence } \\
(\mathbf{c m})\end{array}$ & $\begin{array}{l}\text { Width of } \\
\text { Inflorescence } \\
(\mathbf{c m})\end{array}$ & $\begin{array}{l}\text { Stem } \\
\text { girth } \\
\text { (cm) }\end{array}$ & $\begin{array}{c}\text { Grain } \\
\text { yield } \\
\text { per } \\
\text { plant } \\
\text { (g) }\end{array}$ & $\begin{array}{l}\text { Grain } \\
\text { yield } \\
\text { per } \\
\text { plot } \\
(\text { g) }\end{array}$ & $\begin{array}{c}\text { Grain } \\
\text { weight } \\
(\mathrm{g} / 10 \mathrm{ml})\end{array}$ \\
\hline 1 & SKGPA-27 & 81.00 & 127.00 & 99.97 & 41.00 & 10.27 & 1.60 & 13.71 & 493.33 & 8.67 \\
\hline 2 & SKGPA-41 & 87.00 & 132.00 & 148.77 & 41.87 & 10.50 & 2.67 & 17.57 & 632.67 & 8.70 \\
\hline 3 & SKGPA-43 & 85.00 & 127.00 & 117.47 & 46.27 & 11.57 & 1.60 & 19.92 & 717.00 & 8.47 \\
\hline 4 & SKGPA-47 & 82.00 & 122.00 & 112.87 & 51.60 & 13.00 & 1.70 & 22.73 & 818.00 & 8.64 \\
\hline 5 & SKGPA-48 & 95.00 & 139.00 & 117.57 & 46.20 & 11.53 & 2.13 & 12.33 & 444.00 & 8.37 \\
\hline 6 & SKGPA-1 & 94.00 & 141.00 & 146.77 & 37.73 & 9.53 & 2.43 & 18.75 & 675.33 & 7.75 \\
\hline 7 & BGA-44 & 84.00 & 135.00 & 100.57 & 38.73 & 9.63 & 2.53 & 10.23 & 368.33 & 8.85 \\
\hline 8 & SKGPA-34 & 94.00 & 139.00 & 118.57 & 44.67 & 11.17 & 2.13 & 16.45 & 592.33 & 8.39 \\
\hline 9 & BGA-51 & 94.00 & 138.00 & 96.67 & 35.47 & 8.97 & 1.07 & 12.04 & 433.67 & 8.47 \\
\hline 10 & SKGPA-28 & 95.00 & 138.00 & 104.47 & 42.13 & 10.60 & 1.60 & 24.01 & 864.33 & 8.94 \\
\hline 11 & SKGPA-21 & 97.00 & 135.00 & 106.37 & 42.33 & 10.63 & 2.13 & 15.15 & 545.33 & 8.44 \\
\hline 12 & SKGPA-52 & 87.00 & 124.00 & 83.70 & 46.33 & 11.66 & 0.96 & 10.73 & 386.33 & 8.42 \\
\hline 13 & BGA-28 & 94.00 & 136.00 & 98.97 & 45.40 & 11.33 & 2.13 & 11.55 & 415.67 & 8.77 \\
\hline 14 & SKGPA-50 & 86.00 & 125.00 & 101.87 & 45.53 & 11.43 & 2.13 & 17.38 & 625.33 & 8.52 \\
\hline 15 & BGA-50 & 96.00 & 137.00 & 123.17 & 45.93 & 11.47 & 1.47 & 19.48 & 701.33 & 8.83 \\
\hline 16 & SKGPA-23 & 87.00 & 131.00 & 113.87 & 42.87 & 10.66 & 1.27 & 9.56 & 344.33 & 9.17 \\
\hline 17 & SKGPA-10 & 86.00 & 133.00 & 98.87 & 39.80 & 9.93 & 0.97 & 11.12 & 400.00 & 8.57 \\
\hline 18 & SKGPA-31 & 95.00 & 139.00 & 87.57 & 37.67 & 9.46 & 2.13 & 15.70 & 566.33 & 8.93 \\
\hline 19 & SKGPA-20 & 97.00 & 139.00 & 85.17 & 34.27 & 8.67 & 1.60 & 11.74 & 422.67 & 8.67 \\
\hline 20 & BGA-43 & 84.00 & 135.00 & 90.67 & 36.13 & 9.07 & 1.47 & 12.81 & 461.33 & 8.94 \\
\hline 21 & BGA-42 & 85.00 & 131.00 & 97.97 & 34.67 & 8.70 & 2.43 & 14.50 & 522.33 & 8.64 \\
\hline 22 & BGA-29 & 85.00 & 120.00 & 91.87 & 38.93 & 9.73 & 1.60 & 12.61 & 454.00 & 9.10 \\
\hline 23 & SKGPA-16 & 94.00 & 140.00 & 98.87 & 41.87 & 10.57 & 1.60 & 19.86 & 715.00 & 8.25 \\
\hline 24 & SKGPA-26 & 95.00 & 134.00 & 91.70 & 38.73 & 9.80 & 1.47 & 10.54 & 379.67 & 8.33 \\
\hline 25 & BGA-49 & 95.00 & 138.00 & 90.67 & 36.67 & 9.13 & 1.07 & 7.90 & 284.33 & 8.44 \\
\hline 26 & SKGPA-18 & 96.00 & 137.00 & 111.37 & 49.93 & 12.50 & 1.47 & 24.33 & 876.33 & 8.54 \\
\hline 27 & RGAS-92-10-1(C) & 83.00 & 125.00 & 124.70 & 52.20 & 13.30 & 1.60 & 21.26 & 765.33 & 8.32 \\
\hline \multirow[t]{2}{*}{28} & Suvarna (c) & 85.00 & 131.00 & 127.47 & 36.67 & 9.27 & 1.36 & 13.06 & 470.33 & 7.87 \\
\hline & Mean & 89.93 & 133.14 & 106.66 & 41.84 & 10.49 & 1.73 & 15.25 & 549.15 & 8.57 \\
\hline
\end{tabular}

Table.2 Analysis of variance for nine quantitative characters in grain amaranth

\begin{tabular}{|c|l|r|r|r|}
\hline \multirow{2}{*}{ Sr. No. } & \multicolumn{2}{|c|}{ Character } & \multicolumn{3}{|c|}{ Source of variation } \\
\cline { 3 - 5 } & & Replication(2) & $\begin{array}{c}\text { Genotypes } \\
\text { d.f.(27) }\end{array}$ & Error (54) \\
\hline $\mathbf{1 .}$ & Days to 50\% flowering & 112.00 & $88.87^{* *}$ & 0.00 \\
\hline $\mathbf{2 .}$ & Days to maturity & 112.00 & $107.71^{* *}$ & 0.00 \\
\hline $\mathbf{3 .}$ & Plant height at maturity (cm) & 1040.12 & $885.85^{* *}$ & 52.53 \\
\hline $\mathbf{4 .}$ & Length of inflorescence (cm) & 91.79 & $75.75^{* *}$ & 15.64 \\
\hline $\mathbf{5 .}$ & Width of inflorescence(cm) & 65.79 & $4.63^{*}$ & 1.03 \\
\hline $\mathbf{6 .}$ & Stem girth(cm) & 0.22 & 0.70 & 0.0012 \\
\hline $\mathbf{7 .}$ & Grain yield per plant (g) & 5.80 & $63.66^{* *}$ & 3.68 \\
\hline $\mathbf{8 .}$ & Grain yield per plot (g) & 7515.68 & $82488.12^{* *}$ & 4774.43 \\
\hline $\mathbf{9 .}$ & Grain weight (g/10ml) & 0.21 & 0.31 & 0.000014 \\
\hline ** Significan
\end{tabular}


Table.3 Components of genetic variation in twenty eight genotypes of grain amaranth for various quantitative characters

\begin{tabular}{|c|l|c|c|c|c|c|c|c|}
\hline $\begin{array}{l}\text { Sr. } \\
\text { No. }\end{array}$ & \multicolumn{1}{|c|}{ Character } & Range & $\begin{array}{c}\text { General } \\
\text { Mean }\end{array}$ & PCV & GCV & $\begin{array}{c}\text { Heritability } \\
\mathbf{h}^{2} \text { (b.s.) }\end{array}$ & $\begin{array}{c}\text { Genetic } \\
\text { advance }\end{array}$ & $\begin{array}{c}\text { Genetic } \\
\text { advance as } \\
\text { \% of mean }\end{array}$ \\
\hline $\mathbf{1}$ & Days to 50\% flowering & $81-97$ & 89.92 & 6.05 & 6.05 & 100 & 11.21 & 12.47 \\
\hline $\mathbf{2}$ & Days to maturity & $120-141$ & 133.14 & 4.50 & 4.50 & 100 & 12.34 & 9.27 \\
\hline $\mathbf{3}$ & $\begin{array}{l}\text { Plant height at maturity } \\
\text { (cm) }\end{array}$ & $83.07-148.77$ & 106.66 & 16.78 & 15.34 & 83 & 30.82 & 28.89 \\
\hline $\mathbf{4}$ & $\begin{array}{l}\text { Length of inflorescence } \\
\text { (cm) }\end{array}$ & $34.67-52.20$ & 41.84 & 14.28 & 10.69 & 56 & 6.91 & 16.51 \\
\hline $\mathbf{5}$ & $\begin{array}{l}\text { Width of inflorescence } \\
\text { (cm) }\end{array}$ & $8.67-13.03$ & 10.49 & 14.25 & 10.43 & 53 & 1.65 & 15.74 \\
\hline $\mathbf{6}$ & Stem girth(cm) & $0.97-2.67$ & 1.73 & 27.98 & 27.90 & 99 & 0.99 & 57.33 \\
\hline $\mathbf{7}$ & Grain yield per plant (g) & $7.90-24.33$ & 15.25 & 31.90 & 29.31 & 84 & 8.46 & 55.50 \\
\hline $\mathbf{8}$ & Grain yield per plot (g) & $284.33-864.33$ & 549.15 & 31.90 & 29.31 & 84 & 8.46 & 55.50 \\
\hline $\mathbf{9}$ & Grain weight (g/10ml) & $7.74-9.10$ & 8.57 & 3.76 & 3.75 & 100 & 0.66 & 7.73 \\
\hline
\end{tabular}

Table.4 Distribution of twenty eight genotypes of grain amaranth into different clusters

\begin{tabular}{|c|c|l|}
\hline $\begin{array}{c}\text { Cluster } \\
\text { number }\end{array}$ & $\begin{array}{c}\text { Number of } \\
\text { genotypes }\end{array}$ & \multicolumn{1}{|c|}{ Name of genotypes } \\
\hline I & 12 & $\begin{array}{l}\text { BGA-51, BGA-49, SKGPA-52, SKGPA-43, SKGPA-21, } \\
\text { SKGPA-34, SKGPA-48, SKGPA-26, RGAS-92-10-1, } \\
\text { SKGPA-50, SKGPA-18, SKGPA10 }\end{array}$ \\
\hline II & 8 & $\begin{array}{l}\text { SKGPA-27, SKGPA-47,BGA-42, SKGPA-41, SKGPA- } \\
\text { 20,BGA-28,BGA-32,BGA-44 }\end{array}$ \\
\hline III & 5 & SKGPA-28, SKGPA-31,BGA-43,BGA-29, SKGPA-23 \\
\hline IV & 1 & SKGPA-16 \\
\hline V & 2 & SKGPA-1,Suvarna \\
\hline
\end{tabular}

Table.5 Average intra (diagonal) and inter (above diagonal) cluster $\mathrm{D}^{2}$ values in 5 cluster of 28 genotypes of grain amaranth

\begin{tabular}{|c|c|c|c|c|c|}
\hline Clusters & Cluster-I & Cluster-II & Cluster-III & Cluster-IV & Cluster-V \\
\hline Cluster-I & $\mathbf{2 5 . 3 5}$ & 52.83 & 100.36 & 37.64 & 112.46 \\
& $(\mathbf{6 4 2 . 6 2 )}$ & $(2791.01)$ & $(10072.13)$ & $(1416.77)$ & $(12647.25)$ \\
\hline Cluster-II & & $\mathbf{2 6 . 3 4}$ & 56.71 & 82.51 & 158.62 \\
& & $\mathbf{( 6 9 3 . 8 0 )}$ & $(3216.02)$ & $(6807.80)$ & $(25160.30)$ \\
\hline Cluster-III & & & $\mathbf{3 0 . 7 9}$ & 131.21 & 208.24 \\
& & & $\mathbf{( 9 4 8 . 0 2 )}$ & $(17216.06)$ & $(43363.90)$ \\
\hline Cluster-IV & & & & $\mathbf{0 . 0 0}$ & 79.41 \\
& & & & & $(6305.95)$ \\
\hline Cluster-V & & & & & $\mathbf{( 0 . 0 0 )}$ \\
& & & & & $\mathbf{( 9 9 6 . 0 3}$ \\
\hline
\end{tabular}

$\mathrm{D}^{2}$ values in parenthesis 
Table.6 Cluster means performance for nine quantitative characters in grain amaranth

\begin{tabular}{|c|l|c|c|c|c|c|}
\hline $\begin{array}{l}\text { Sr. } \\
\text { No. }\end{array}$ & Clusters & Cluster-I & $\begin{array}{c}\text { Cluster- } \\
\text { II }\end{array}$ & $\begin{array}{c}\text { Cluster- } \\
\text { III }\end{array}$ & $\begin{array}{c}\text { Cluster- } \\
\text { IV }\end{array}$ & $\begin{array}{c}\text { Cluster- } \\
\text { V }\end{array}$ \\
\cline { 1 - 6 } 1. & Characters & & & & & \\
\hline 2. & Days to 50\% flowering & 91.08 & 88.25 & 89.20 & 94.00 & 89.50 \\
\hline 3. & Plant to maturity & 132.83 & 132.38 & 132.60 & 140.00 & 136.00 \\
\hline 4. & Length of inflorescence (cm) & 43.68 & 41.68 & 39.55 & 41.87 & 37.20 \\
\hline 5. & Width of inflorescence(cm) & 10.94 & 10.45 & 9.91 & 10.57 & 9.40 \\
\hline $\mathbf{6 .}$ & Stem girth(cm) & 1.56 & 20.02 & 1.61 & 1.60 & 1.90 \\
\hline 7. & Grain weight (g/10ml) & 8.45 & 8.72 & 9.02 & 8.25 & 7.81 \\
\hline 8. & Grain yield per plant (g) & 14.93 & 15.19 & 14.94 & 19.86 & 15.91 \\
\hline 9. & Grain yield per plot (g) & 537.47 & 546.79 & 538.07 & 715.00 & 572.83 \\
\hline
\end{tabular}

Table.7 Percent contribution of various quantitative characters to divergence in grain amaranth

\begin{tabular}{|c|l|c|}
\hline $\begin{array}{c}\text { Sr. } \\
\text { No. }\end{array}$ & \multicolumn{1}{|c|}{ Characters } & Per cent contribution \\
\hline $\mathbf{1 .}$ & Days to $50 \%$ flowering & 1.32 \\
\hline $\mathbf{2 .}$ & Days to maturity & 2.65 \\
\hline $\mathbf{3 .}$ & Plant height at maturity $(\mathrm{cm})$ & 0.00 \\
\hline $\mathbf{4 .}$ & Length of inflorescence $(\mathrm{cm})$ & 0.00 \\
\hline $\mathbf{5 .}$ & Width of inflorescence $(\mathrm{cm})$ & 0.00 \\
\hline $\mathbf{6 .}$ & Stem girth $(\mathrm{cm})$ & 8.20 \\
\hline $\mathbf{7 .}$ & Grain weight $(\mathrm{g} / 10 \mathrm{ml})$ & 87.83 \\
\hline $\mathbf{8 .}$ & Grain yield per plant $(\mathrm{g})$ & 0.00 \\
\hline $\mathbf{9 .}$ & Grain yield per plot $(\mathrm{g})$ & 0.00 \\
\hline
\end{tabular}

Figure 1 Distribution of different cluster combination into four divergence classes based on $D$ values between them.

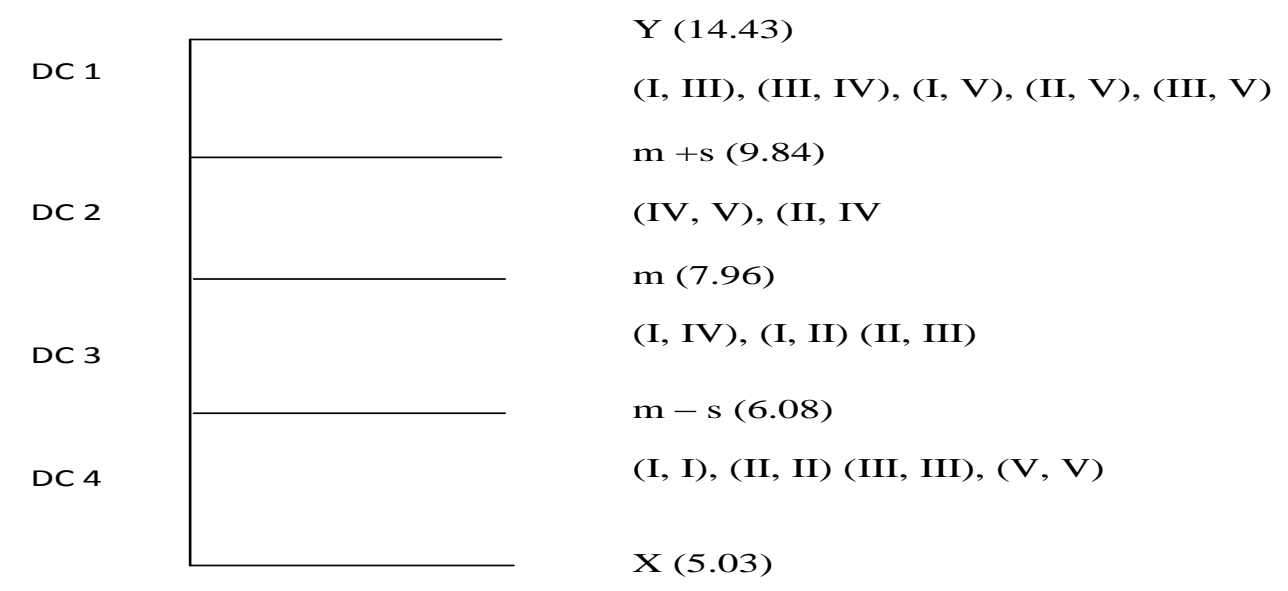


The high estimates of genotypic and phenotypic coefficient of variation were observed for the traits viz., grain yield per plant (29.31 GCV and 31.90 PCV), grain yield per plot (29.31 GCV and $31.90 \mathrm{PCV}$ ), plant height at maturity $(15.34 \mathrm{GCV}$ and 16.78 PCV), length of inflorescence (10.69 GCV and 14.28 PCV), width of inflorescence (10.43 GCV and 14.25 PCV) while low estimates were observed for the character days to $50 \%$ flowering (6.05 GCV and 6.05 PCV), days to maturity (4.50 GCV and 4.50 PCV), grain weight (3.75 GCV and 3.76 PCV). These results are in conformation with Joshi (1986) showed a wide range of variability for plant height, number of leaves per plant, leaf length, leaf width inflorescence length, number of spikelets per plant days to maturity, seed yield per plant in grain amaranth. Pawar (1995) observed higher estimation of GCV and PCV in grain amaranth. Lohitswa et al., (1996) reported considerable amount of phenotypic and genotypic variability for grain yield followed by plant height in grain amaranth. In some characters like width of inflorescence, length of inflorescence shows the large difference in G.C.V and P.C.V which indicate that these characters are highly influenced by environmental factors. While in case of grain weight, stem girth, days to $50 \%$ flowering, Days to maturity the estimate of G.C.V. and P.C.V. were nearly equal, indicating that the variability existing in these character was due to genetic factors.

In the present investigation, the characters $v i z$., days to $50 \%$ flowering, days to maturity, grain weight, plant height at maturity, stem girth grain yield per plant, grain yield per plot expressed high estimates of heritability in broad sense indicating the scope for selection of these traits. The traits viz., length of inflorescence and width of inflorescence showed comparatively less heritability which suggests that the selection for such characters will not be much effective. However, Joshi (1986) reported that the high heritability estimates as a tool in selection programme for still better efficiency in selection. In the present study days to $50 \%$ flowering, days to maturity and grain weight showed highest heritability $100 \%$ coupled with genetic advance $11.21,12.34$ and 0.66 respectively.

Genetic advance for grain weight was low but when expressed as percentage means it was fairly high. In case of days to $50 \%$ flowering, days to maturity, grain weight, stem girth high heritability is coupled with low genetic advance. The trait grain yield per plot recorded highest genetic advance where as grain weight having lowest genetic advance. The character with high heritability estimates associated with high genetic gain may be governed by additive gene effects and can effectively be improved by simple selection (Panse 1957). On the other hand the trait exhibiting high heritability and low genetic gain may be governed by the non additive gene effects (dominance and epistasis). The character showing such inheritance can be improved through hybridization. The low heritability estimates suggests that selection for such characters will not be much effective. Thus considering the estimates of genetic parameters like G.C.V., heritability and genetic advance together grain weight, days to $50 \%$ flowering, days to maturity, stem girth, grain yield per plant and grain yield per plot could be more effective traits, for improvement in grain amaranth.

The several groups of genotypes configuration may admit a description in terms of a few group constellations and their interrelationship. Mahalanobis (1936) distance statistic $\left(\mathrm{D}^{2}\right)$ is useful tool for this and is now well established and widely used in plant breeding for classifying the genetic stocks, on the basis of genetic divergence between populations. The cluster I comprised 
most of the genotypes i.e. 12 while cluster II had 8 genotypes, cluster III had 5genotype, cluster IV is monogenotypic and cluster V had 2 genotypes.

The maximum inter cluster distance was observed between cluster III and V $\left(D^{2}=\right.$ 208.24) suggesting that genotypes included in cluster III might have entirely different genetic architecture from the genotypes included in the cluster VIII. The cluster distance between II and V was 158.62 followed by cluster III and IV was 131.21, Cluster I and V was 112.46, Cluster I and III had 100.36. Greater the reduction in differences between cluster distances results into higher close proximity of genotypes present in those clusters. The $\mathrm{D}^{2}$ values indicated that the cluster III and V had maximum divergence $\left(D^{2}=43363.897\right)$ from the rest of clusters as well as from each other. The variation of cluster means provides information on relative importance of characters towards the divergence.

The variance of cluster mean was much higher for grain weight followed by days to maturity, stem girth and days to $50 \%$ flowering. The selection of best parents having high potential for the economically important characters is the success of any crop improvement. Arunachalam and Bandyopadhyay (1984) devised method to delineate parental divergence into four divergence classes (D.C). To take into account the variable magnitude of variation in parental divergence, the mean (m) and standard deviation (s) of the values of intra and inter cluster divergence (D) were calculated. They defined divergence classes as below:

$\begin{array}{lll}\text { DC1 } & : & \mathrm{D}(\mathrm{m}+\mathrm{s}) \\ \mathrm{DC} 2 & : & \mathrm{D}<(\mathrm{m}+\mathrm{s}) \text { and } \mathrm{m} \\ \mathrm{DC} 3 & : & \mathrm{D}(\mathrm{m}-\mathrm{s}) \text { and }<\mathrm{m} \\ \mathrm{DC} 4 & : & \mathrm{D}<(\mathrm{m}-\mathrm{s})\end{array}$

In the present study, an attempt was made to classify the cluster combinations into four divergence classes. The mean of 5 inter cluster and 4 intra cluster (as monogenotypic cluster IV had no intra cluster distance) was 7.96 and the standard deviation was 1.88. The minimum (X) and maximum $(\mathrm{Y})$ values among these distances were 5.03 and 14.43 respectively. Grouping of cluster pairs into these divergence classes (Figure 1), on the light of the above discussion, initial choice of the parents could be made from the cluster combinations.

In conclusion the present investigation "Genetic diversity of future important underutilized crop grain amaranth (Amaranthus hypochondriacus L.) genotypes based on cluster" was undertaken with twenty eight genotypes to measure genetic diversity in quantitative characters. Twenty eight genotypes were planted in $45 \times 15 \mathrm{~cm}$. spacing in RBD design with three replication in rabi 2011-12. The 28 genotypes were evaluated for nine quantitative characters to have clear view of yield contributing components. The observations recorded were days to $50 \%$ maturity, Days to flowering, plant height at maturity, length of inflorescence, width of inflorescence, stem girth, grain yield per plant, grain yield per plot and grain weight.

Wide range of variation was observed for all the nine characters. The analysis of variance exhibited significant differences among the genotypes for all the nine characters indicating the presence of substantial degree of variability. Phenotypic Coefficient of Variation (PCV) was found to be more than (Genotypic Coefficient of Variation (GCV) for all nine characters indicating the role of environment for expression of the characters. The grain yield per plant and yield per plot exhibited the highest GCV (29.31) and PCV (31.90) followed by length of inflorescence. The character grain weight had least GCV and PCV.

Heritability (b.s.), for the characters viz., days to $50 \%$ flowering, days to maturity, grain weight, plant height at maturity, stem girth, grain yield per plant, grain yield per plot expressed high estimate of heritability in broad sense indicating the scope for selection of these characters.

In the present investigation, $\mathrm{D}$ values between 25.35 and 208.24. The genotypes were grouped 
into 5 clusters. Cluster I contain maximum number of genotypes (12) while cluster II had 8 genotypes. Cluster III had 5 and cluster V had 2 genotypes while cluster IV was monogenotypic. $\mathrm{D}^{2}$ values ranged 642.62 to 43363.90 . The maximum inter-cluster distance was observed between cluster III and V (43363.90) followed by cluster II and V (25160.30).

\section{References}

Arunachalam, V. and A. Bandyopadhyay. 1984. Limits to genetic divergence of heterosis - experimental evidence from crop plants. Indian J. Genet. 49 (3): 548-554.

Burton, G.W. 1952. Quantitative inheritance in pearl millet ( $P$. glanacum L.) Agron. J. 50: 503.

Candolle, A. De. 1883. Origine des plantes cultivees, Paris.

Johnson, HW, Robinson, HF Comstock, RE Estimation of genetic and environmental variability in soybeans. Agronomy J. 1955 47: 314-318.

Joshi, B.D. 1985. Collection, evaluation and conservation of grain amaranth, buck wheat and chenopod, IIIrd workshop of AICRP on under utilized and under exploited crop and plants, held at NBPGR, New Delhi on 30th June and 1st July, J. 985. pp. 1-20.

Joshi, B.D. 1986. Genetic variability in grain amaranth, Amaranth hypochondriacus Linn. Indian J. Agric. Sci. 56: 574 - 576.

Kamble, A.K. 2000. Genetic divergence and path analysis in Grain amaranth. M.Sc. (Agri.) thesis submitted to M.P.K.V., Rahuri.
Lohithaswa, H. C., T. E. Nagraj, D. L. Savithramma and H. B. Hemareddy 1996. Genetic variability studies in grain amaranth. Mysore J. Agric. Sci. 30 (2): 117-120.

Mahalanobis, P.C. 1936. On generalized distance in statistics. Proc. Nat. Ins. Sci. India. 2: 49-55.

Panse, V.G. 1957. Chromosome number in some Indian Angiosperms - I: Proc. Indian Acad, Sci. 9: 5 (B): 347-350.

Panse, V.G. and P.V. Sukhatme. 1985. Statistical methods for agricultural workers. ICAR, New Delhi. Ed. 4 pp. 359.

Pawar, A.N. 1995. Genetic diversity and path analysis in amaranth. M.Sc. (Agri.). thesis submitted to M.P.K.V., Rahuri.

Rao, C. R. 1952. Advanced statistical methods in biometrical research. John Wiley and Sons. Inc., New York. 62

Ravindran, V., R.L. Hood, R.J. Gill, C.R. Kheale, and W.L.Bryden. 1996. Nutritional evaluation of grain amaranth (A. hypochondriacus L.) in broiler diets. Animal Feed Sci. and Technology. 63: 14.

Sauer, J.D. 1967. The Grain amaranth and their relatives: A revised taxonomic and geographic survey. Ann. Missouri Bot. Garden. 54: 103-137.

Singh, R. K. and B. D. Chaudhari. 1977. Biometrical techniques in Genetics and Breeding. pp. 163-191.

Vavilov, N.I. 1951. The origin, variation, immunity and breeding of plants. New York. Ronald Press. Co. pp. 364.

\section{How to cite this article:}

Raut, V.A., S.S. Dodake and Magar, N.M. 2020. Genetic Diversity in Future Important under Utilized Crop Grain Amaranth (Amaranthus hypochondriacus L.) Genotypes based on Cluster. Int.J.Curr.Microbiol.App.Sci. 9(12): 1987-1996. doi: https://doi.org/10.20546/ijcmas.2020.912.235 